\title{
Fascist World Literature from Latin America
}

\author{
The Case of Miguel Serrano
}

\section{Alternative forms of World Literature: The Global Alt Write}

In view of the current multiple political, economic, and humanitarian crises in the world, recent scholarship on World Literature has started to critically examine some of the fundamental assumptions in the field since its (re-)emergence about 20 years ago (cf. Müller/Siskind 2019). This concerns, in particular, an affirmative and optimistic notion of (neo)liberal globalization and cosmopolitanism that underlies many of the theoretical contributions within the field. Consequently, this critical examination also brings up the question of how to deal with texts and authors that do not conform (aesthetically and/or ideologically) to the prevailing emancipatory notion of World Literature, but that, nevertheless, circulate worldwide and have important impacts on a global scale. This problem applies, as I have argued elsewhere more in detail (cf. Loy 2019), particularly to texts whose political and ideological orientations contravene the hegemonic liberal and leftist positions of World Literature studies (and the Humanities as a whole), namely those belonging on the right-wing, reactionary, and fascist side of the spectrum.

Contrary to cosmopolitan assumptions that global circulation mainly is an issue related to "progressive" or emancipatory texts, these ideologies - and their literary adaptations - have been circulating since the early anti-Enlightenment time up until today on a global scale, shaping their own politico-aesthetical sphere with specific canons, actors, publishers, and networks. However, scholarship of World Literature has not dedicated much attention to this "Global Alt Write" and its modes of operation ${ }^{1}$. This holds particularly true for Latin America, which has

1 Exceptions include a couple of studies on the cultural dimensions of historical fascisms such as Venkat Mani's analysis of political (ab)uses of World Literature in Nazi Germany (cf. Mani 2017: 131-178), Federico Finchelstein's work on Transatlantic Fascism, or Benjamin G. Martin's study on international fascist cultural politics as a "model of transnational cooperation based on the values of the most intense, aggressive, and racist national spirit” (2016: 7). Contrary to this, in the history of ideas and political science there has been an ongoing debate

Benjamin Loy, Universität Wien

Ә Open Access. (c) 2021 Benjamin Loy, published by De Gruyter. (cc))BY-NC-ND This work is licensed under a Creative Commons Attribution-NonCommercial-NoDerivatives 4.0 International License.

https://doi.org/10.1515/9783110713015-014 
traditionally been read as a productive "supplier" of all sorts of theories and models of progressively adaptable cultural or literary hybridity, but rarely as a site of transnational circulation of reactionary thinking and literature, despite the fact that the region has had an equally strong tradition of such thinking (cf. Loy 2020). An exemplary figure of this kind of contemporary Fascist World Literature is the Chilean author Miguel Serrano (1917-2009). His works have not only been translated into more than 20 languages all over the world, but he also continues to be a global cultural phenomenon in reactionary and neo-Nazi circles, where his citations are printed on T-shirts sold in Italian neo-fascists' web shops and his concept of "esoteric Hitlerism" is debated in hour-long conversations by US-American white supremacists on YouTube.

"Political and broader ideological factors may trigger or hinder the circulation of literary texts. Translation may serve political or ideological objectives; it can be a means to disseminate a doctrine or a vision of the world" (Sapiro 2016: 83), annotates Gisèle Sapiro in her sociological approach to factors of circulation within World Literature. The examples she thinks of are naturally those, "where the institutions governing cultural production as well as the organization of intellectual professions are state-run, as in fascist or communist countries, [and where] the production and circulation of symbolic goods are highly politicized" (Sapiro 2016: 84). However, global fascist thinking and literature after World War II shows that ideology, as a factor of transnational circulation, does not necessarily rely on strong state-based cultural politics and apparatuses. In particular, the existence of fascist literature in times after the historical collapse of its principal historical promoters (Nazi Germany and Fascist Italy) illustrates the necessity to take alternative forms of ideology-driven and global circulations of literature into account. As the following analysis of Miguel Serrano's work will show, there are specific factors that have contributed to the worldwide reception of his writings. Apart from determinate cultural and political networks and actors closely related to Serrano's long career as a Chilean diplomat, among which are prominent figures such as Hermann Hesse, Carl Gustav Jung, and Indira Gandhi, the specific relationship between fascism and esotericism in his work was largely what contributed to its global circulation. Furthermore, we will analyze the role of independent publishers acting as principal promoters of a "fascism from below" within the context of Miguel Serrano's work. But first, we have to clarify information about his biography and ideological cosmogony in the wake of "esoteric Hitlerism”.

on the transnational character of the right for years (cf. for example the volumes by Durham/ Power 2010 or Mammone/Godin/Jenkins 2013). 


\section{Miguel Serrano and Global Esoteric Fascism}

Miguel Serrano was born in 1917 in Santiago de Chile as part of a bourgeois family, whose most renowned member was his uncle Vicente Huidobro, one of the iconic figures of the Latin American avant-garde movements. After feeling drawn to socialist ideas in his early youth, Serrano, shortly thereafter, turned to fascism in the late 1930s, the same time when he began to rise to his status as a literary star in his homeland and one of the leading authors of the famously named generación del 38. As Natalia Figueroa has pointed out, the characteristic traits of this generation were the search for national identity, a strong link to ideological and artistic movements in Europe, and a manifest interest in esotericism (Figueroa 2018: 23-24). The latter, in particular, promoted the start of Serrano's international literary career, framing him as an author of esoteric stories with titles such as, The Visits of the Queen of Sheba (1973), The Serpent of Paradise: The Story of an Indian Pilgrimage (1974), Elella: Book of Magic Love (1972), or Nos: Book of the Resurrection (1984). Especially when serving as Chilean Ambassador in India (1953-1962) (and later in Yugoslavia, from 1962-1965, and Austria, from 1965-1971), Serrano developed his own cosmogony of “esoteric Hitlerism”, which he would expose in the trilogy The Golden Thread: Esoteric Hitlerism (1974), Adolf Hitler, the Last Avatar (1984), and Manú, for the Man to Come (1991). The combination of esotericism and its occult elements with fascism is not unusual, considering that occultism played a crucial role in the ideological formation of German Nazism (cf. Sedgwick 2004: 95-117, Mosse 1966: 13-148). The same goes for the contemporary extreme right, whose interest in all kinds of occultism, Satanism, and conspiracy theories can be considered "a result of the neo-Nazis' failure to achieve any political philosophy, thus leading them to move away from political activism and take refuge in cults that are accessible only to an elite of cognoscenti” (Camus 2013: 113). The case of Miguel Serrano's “esoteric Hitlerism”, however, is to be judged as a "globalist" form of ideology, as it "weaves together disparate global elements in ways that did not and could not have existed before global communication was possible" (Versluis 2013: 131). By creating a hybrid between Hindu and Western esoteric elements, thereby forming a "global syncretic neo-esotericism" (Versluis 2013: 122), Serrano draws on a long tradition of global occultist thinking characterized by its manifest critique of Western modernity and its leading principles of rationality, subjectivity, and democratic secularism. Serrano subscribes himself to an anti-modernist imaginary that, contrary to what its essentialist core might suggest, is truly global, as it connects directly to the specific "mix of racism and cosmopolitanism, science and the supernatural" (Kurlander 2017: 17), that characterized the ideological geopolitics of the Nazis. As Nicholas Goodrick-Clark argued in his groundbreaking study, the post-war 
wave of Nazi fugitives to South America caused an authentic transfer of ideology, coalescing Aryan mythology and traditional Latin American racist attitudes. "The multiracial composition of Latin America thus interacted with anti-Semitic Nazi racism to elaborate a new Thulean myth of Aryan settlement in the Southern Hemisphere" (Goodrick-Clark 2002: 173).

In what follows, we will consider the esoteric and fascist dimensions of Miguel Serrano's international reception and circulation separately, in terms of publishers, translations, and other book market-related parameters. However, epistemologically both aspects are intrinsically linked to each other in their shared refusal of the foundations of Western modernity. The distinctive feature of this kind of occultist, esoteric, and mythological thinking lies both in a search for an essentialism threatened by modernity and in an "attempt to understand the world as a network of mutually related sympathies or analogies" (Bogdan/Djurdjevic 2013: 2). Contrary to common assumptions, essentialism and analogy-driven network-thinking are not mutually exclusive concepts. From the vantage point of both esotericism and fascism, the sin of modernity is its ability, according to Marx, "to melt all that is solid into air", to dissolve the idea of a homogenous society and an ordered world, pushing human beings towards what Lukacs famously coined as "transcendental homelessness". The task of this reactionary thinking, thus, is to fight modernity's contingencies and to transform the world into a (supposedly) coherent space, where every element finds its "logical" place within a holistic order. The genuine world-making character of reactionary thinking stems from there, as no element - history, nature, language, society, race - can be said to exist outside of or independently from the basic explanatory principle of its weltbild. Consequently, the core of the ideological project of reaction is to create a narrative of the world as a space of regained order and resonance (cf. Rosa 2019), as these are the two main principles threatened by modernity's “devastating” effects, dynamics and dissolution.

Without going into detail here (cf. Goodrick-Clark 2002: 173-192, Versluis 2013: 124-131), it is clear that Miguel Serrano's concept of “esoteric Hitlerism” is representative of this equally essentialist and correlative-oriented (more precisely, paranoid) type of thinking. Influenced by racist theories by authors like Arthur de Gobineau and Nicolás Palacios, and occultist icons like René Guénon (cf. Sedgwick 2004) and Julius Evola, Serrano proposes a Gnostic and Manichaean cosmogony, whose universe is determined by a fight between an evil Demiurge and the descendants of a Supreme Deity. According to Serrano's racist and anti-Semitic world view, the agents of evil are the Jews, while the divine descendants, who migrated from Northern Europe to the South Pole and South America long before Columbus's arrival to the continent, are called the Hyperborean Aryans. This framework, first articulated by the French Nazi-writer and former SS-member 
Jacques de Mathieu (cf. Goodrick-Clark 2002: 183-185), allows Serrano, not only to create a mythologically grounded counter-history, but also to conceive of (South) America as an originally racially "pure”, Aryan continent. In-line with this conception of white supremacy, the "racial decline" of South America would have begun with the fatal "cross-breeding" of racially inferior Spanish colonists and indigenous American people (cf. Serrano 1987: 27-28). However, following a redemptionist conception of history, characteristic of reactionary thinking, Serrano cherishes the hope that the White Gods, hidden in the secret cities of the Andes, in the hollow earth, and in Antarctica, will return to redeem America (and the world) from modernity's scourges, which he equates to the global Jewish conspiracy, the human alienation, and domination by capitalism and technology. Needless to say that Serrano, who worked as an active Nazi-propagandist in Chile during World War II, considers Adolf Hitler, much like his famous friend Savitri Devi ${ }^{2}$ (cf. Versluis 2013), to be one of these god-like "Avatars", waiting in a secret place in South America for their moment to come. It is this mixture of "classical" antimodernist racism, anti-Semitism, and white supremacy, on the one hand, and elements of esotericism and occultism, such as a mystic conception of language ${ }^{3}$ and landscape, the existence of parallel universes, UFOs, and secret places like the hollow earth, on the other, that characterize Serrano's syncretistic reactionary project. However, it is precisely this hybrid character and its specific "exotic" branding, due to the inclusion of Latin American and Hindu elements, that contributed to Serrano's international reception and marketability in esoteric and neo-fascist circles around the world.

\section{The Gatekeepers' Myth: Miguel Serrano, Carl Gustav Jung, and Hermann Hesse}

Serrano's international literary career started in 1960 during his time as Chilean Ambassador in India, with the publication of Las visitas de la reina de Saba (The Visits of the Queen of Sheba). The book was published simultaneously in New Delhi and Bombay in both Spanish and English, and contains esoteric reflections mixed with spiritual stories about Serrano's perception of Hindu culture. However, the most interesting point about the book is that the preface was

2 Serrano calls her "una sacerdotisa odínica, del Hiterlismo Esotérico, la primera en reconocer la aparición del Avatâra y la divinidad de Hitler” (1986: 9)

3 For more information about mystic language and pseudo-philological arguments, since Serrano constantly uses them too, see the arguments in Eco 1995. 
written by Carl Gustav Jung. The argument here is that the founder of analytical psychology, together with Nobel Prize winner Hermann Hesse (who Serrano got in touch with for the first time in 1951), acted with their cultural capital as a kind of gatekeepers (cf. Marling 2016) for Serrano's international takeoff. By conferring a sort of higher spiritual and literary consecration upon Serrano's esoteric works, they contributed (unwittingly) to the international reception of the works in a crucial way. Furthermore, we will argue that this form of consecration did not occur, as Serrano tried to depict it with his mythological terms, by chance or "destiny". It rather must be considered a well-aimed and deliberate operation organized by the Chilean author to make use of the fame of both authors.

Serrano describes his relationship with Jung and Hesse in what would become his most-translated work, El círculo hermético: de Hermann Hesse a C. G. Jung, published for the first time in 1965 in Santiago de Chile by the prestigious Editorial Zig-Zag. Apart from its quick translation into English, published in 1966 by the equally prestigious publisher Schocken (and then in more than 20 additional editions by Schocken and Harper \& Row), the book was translated into German, French, Italian, Portuguese, Japanese, Slovenian, Turkish, Persian, Serbian, and Croatian, among other languages. This being said, the titles of some of the translations are somewhat misleading. Both the English version, C.G. Jung and Hermann Hesse: a Record of Two Friendships, and one of the French versions, Le cercle hermétique: testaments littéraires de Hermann Hesse et CarlGustav Jung, suggest that the book is about the relationship between the two famous men, rather than what Serrano's book actually is about: a couple of visits he made to Hesse and Jung in Switzerland and his resulting correspondence with them. The part about Hesse (cf. Serrano 1974: 19-53) begins with Serrano's description of his own lectures on Hesse's works, then continues to depict the three visits Serrano made to Hesse in his house in Montagnola in the 1950s, followed by the content of their occasional correspondence. Hesse welcomes Serrano's visits because they allow him to ask the Chilean author to check his own translations into Spanish and to talk about the incipient reception of Latin American authors in the German-speaking world. [L]a editorial española Aguilar está ya publicando mis obras completas. Le ruego que las vea y me diga si son fieles. ambién en Alemania estamos en plena invasión de traducciones de la lengua española. Y Hesse me extiende una edición alemana del escritor venezolano Rómulo Gallegos. (Serrano 1974: 41). Contrary to this rather practical interest on the part of Hesse, Serrano tries to evoke the impression of a mystical bond between himself, Hesse, and, later on, Carl Gustav Jung. He enlarges their rather banal conversations about India and esoteric topics in order to invoke the idea of a deep relationship between the German master and his Chilean disciple. "Hesse 
se parecía a un maestro chino y también a un árbol sabio" (Serrano 1974: 35). The reader's perception, however, is dominated by an impression of Serrano as a kind of obtrusive stalker, creeping around Hesse's house and spying on him while he is working in his garden. The bizarre climax of this part of the book about Hesse is Serrano's description of a kind of necromantic ritual that he carries out in Beograd after Hesse's death. He describes this ritual in detail in a last letter to Hesse's widow, Ninon, whose Jewish descent is not mentioned anywhere in the strategically-grounded praise the anti-Semitic Serrano writes.

Even more important, in terms of both strategic connection and direct intellectual influence on Serrano, was his relationship with Carl Gustav Jung, whom Serrano had admired since his youth (cf. Serrano 1974: 55). In 1957 - and thanks to a contact established via Indira Gandhi, with whom Serrano met regularly in India - the Chilean author started correspondence with Jung. Similar to his strategy with Hermann Hesse, Serrano visits Jung two times in Küsnacht in 1959. Despite the obviously intrusive character of his appearance at Jung's home in Switzerland, Serrano depicts their brief encounter in his usual mystical tone as an, "intervención de fuerzas ocultas en este mundo" (Serrano 1974: 76). His insistence seems to have paid off when Jung authorized him to use a letter to Serrano as the foreword to The Visits of the Queen of Sheba. Jung praises the work with the following words:

This book is an extraordinary piece of work. It is dreams within dreams, highly poetic I should say and most unlike the spontaneous products of the unconscious I am used to, although well-known archetypic figures are clearly discernible. [. . .] the effect on the reader captivates him in an increasing dream, in an ever-extending space and an immeasurable depth of time. On the other hand, the cognitive element plays no significant role, it even recedes into a misty background yet alive with the wealth of colourful images, [. . .] an approach to wholeness, the one experience absent in our modern civilization. It is the avenue and via regia to the Unus Mundus (Jung in Serrano 1973: vii)

Jung's judgment illustrates to what extent Serrano's esoteric and anti-modernist positions shared important connections to Jung's own psychological concepts of archetypes and the unconscious. Serrano makes these connections, and notably their political implications, evident in a letter to Jung written in Delhi on May 7, 1960:

[E]l Occidente ha agotado la posición racional; insistiendo en ella, sólo producirá desgracia para sí mismo y para el mundo. Se hace necesario un cambio. Por eso le decía al profesor Toynbee que era mejor para el hombre blanco occidental retirarse entre bastidores y dejar a los otros hacer por ahora el trabajo externo, el de la política, el del mundo en general. No hay posibilidad de contrarrestrar la lógica aplastante del marxismo, del materialismo histórico, dentro de la dialética racionalista, como no hay posibilidades de probar la 
inmortalidad del alma, o su existencia, racionalmente. La evidencia de esto último se halla en otro sitio, en otras fuentes que no dependen de la razón. Por lo demás, dentro de la razón no hay evidencia posible. Lo que hoy es cierto, mañana no lo es. Es un mundo inestable por antonomasia. Los indios, que piensan pensamiento distintos, procedentes de fuentes no racionales, carecen, por lo mismo, de la lógica racional consistente de los occidentales. [ . . .] El Occidente, en cambio, tendrá que aprender a ser ilógico. Es la única manera de poder combatir al comunismo, al estatismo y a la esclavitud de la persona. (Serrano 1974: 83)

According to Serrano, due to the decadence of the West, which was caused by modernity's rationalism, the task of reconquering the parallel world of myth and the "illogic" becomes the primary necessity in order to overcome, not only the individual "slavery" of human beings, but also the threat of communism. Serrano explicitly praises Jung and his theories, citing them as examples to follow, by highlighting his "trabajo de la revivificación de los símbolos, tratando de encontrar nuevamente el lazo perdido, cortado, entre la Ciencia y la Alquimia, o, mejor dicho, entre la Ciencia y el Alma" (Serrano 1974: 84). Serrano considers Jung, as he writes in another letter to him, as a contemporary representative of the "hermetismo del pasado; ha encontrado la conexión, el camino, el sendero oculto que se había perdido con advenimiento del Siglo de las Luces. [. . . L La trayectoria del hombre esencial halla nuevamente un cauce gracias a usted. Meister Eckhart es así confirmado" (Serrano 1974: 101). While in his letters to Jung, Serrano discusses more general topics, such as the critique of Western subjectivity and individuality or the necessity to transcend language in order to regain magic symbolism (cf. 84-85), his "esoteric Hitlerism" was heavily influenced by Jung's "Wotan" essay, dating back to $1936^{4}$. Without going into detail about the text and its complex implications, it is important to note that Serrano's racialized Gnostic worldview shares important features with Jung's thinking, such as the ideas of archetypes and the relation between the collective unconscious and national rebirth. Recent scholarship also highlighted the fact of Jung's favorable attitude towards Hitler and National Socialism in the 1930s, arguing that "[t]he concept of a racially and religiously differentiated phylogenetic unconscious underlies the basic premises of the 'Wotan' essay and is the bridge that connects Jung's universalist and exclusivist definitions of archetypes" (Dohe 2016: 5).

However, it is more important for the present topic of Serrano's international circulation to highlight, once again, the strategical use Serrano makes of his exchange with Jung. This becomes evident if we consider, for example, the complete reprint of a ten-page, completely illegible letter from Jung to Serrano

4 For more information about the significance of this essay for the global movement of the Extremist Right's Wotanvolk, see Goodrick-Clark (2002: 269-275). 
in the cited version of El círculo hermético. The caption reads: "Carta de extraordinaria importancia, escrita por el Profesor Jung poco antes de su muerte y que viene a ser como su testamento ideológico. Esta carte fue escrita enteramente a mano por el Profesor Jung, mientras permanecía enfermo en cama” (Serrano 1974: 80). The reprint here functions primarily as an act of material attestation of Serrano's own alleged importance, as he highlights the presumable letter as "ideological testament", written by Jung who is virtually on his deathbed, sent over to his “disciple” Miguel Serrano. A photograph showing Serrano with India's Prime Minister Jawaharlal Nehru (Figure 1), whom he is communicating to about Jung's death in 1961, fulfills the same function. The description of this event - like so many others in Serrano's exaggerated letters - is not free from (unintended) humor. According to Serrano's own words, he approaches Nehru on the airfield in Delhi, Nehru already being on his way to Nepal for his holidays. This is why he asks the Chilean ambassador to write a note of condolence on behalf of the Indian people. Naturally, Serrano accepts this mission and states, full of solemnity, "Y fue así como la India se hizo presente a la muerte de quien tanto hiciera por comprender los profundos valores de su civilización, para confrontarlos con los del mundo occidental y enriquecerlo. Otro gran Círculo se cerraba” (Serrano 1974: 102).

However ridiculous Serrano's servile approaches and mystifying (ab)use of Hesse and Jung's scarce testimonies about his person and writings may appear, they were doubtlessly a crucial factor in the following international reception of his esoteric writings. The Serpent of Paradise: The Story of an Indian Pilgrimage and The Ultimate Flower, for example, were both immediately translated into English and published by an important English publisher, Routledge and Kegan Paul. In the German and French market, however, his books appeared in independent publishing houses that specialized in esoteric literature, as was the case for the German translations of Die Besuche der Königin von Saba (Aurum-Verlag 1980), El - ella. Das Buch der Magischen Liebe, and Auf der Suche nach der verborgenen Blume: eine südamerikanische Legende, all published at Sphinx-Verlag in Basel (1982/1984). All of these works were preceded by the German translation of Meine Begegnungen mit C. G. Jung und Hermann Hesse in visionärer Schau (Rascher Verlag 1968), which seems to confirm the hypothesis that places Jung and Hesse as intellectual door-openers for Serrano. The importance of their role can furthermore be recognized by considering the para-textual fact that many of the book's translations' covers depict Serrano and Hesse in Montagnola (Figure 2), and that virtually none of the back covers of Serrano's numerous translations ever omits mentioning that Hesse and Jung were Serrano's (supposedly) intimate friends.

However, the irritating point about Serrano's success in the field of global esotericism concerns the fact that his esoteric works have been continuously read 


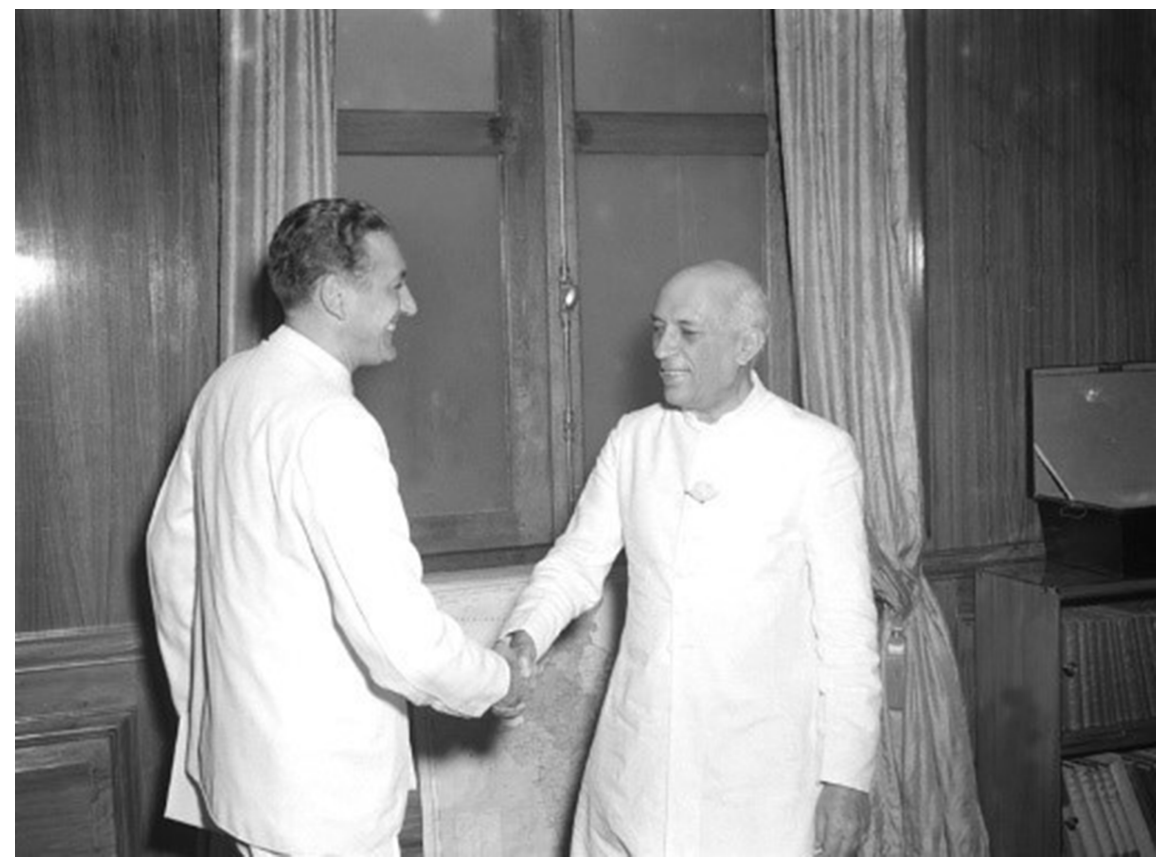

Figure 1: The Prime Minister, Shri Jawaharlal Nehru greeting the Chilean Ambassadordesignate to India, Mr. Miguel Serrano Fernández, when the latter called on him at the Minister of External Affairs, New Delhi on May 30, 1957. Photo division Government of India. Photo Number: 59108.

and (re-)translated, even in the recent past. That means that long after his trilogy of texts featuring "esoteric Hitlerism" and his fame in neo-Nazi circles should have destroyed his once carefully constructed (self-)image as a presumably "innocent" cosmopolitan and spiritualist writer of folk tales from Chile and India, his overt anti-Semitism and Nazi-praise was completely ignored by his esoteric readers and publishers. For example, the biographical information about Serrano on the back cover of the recent French translation of Les visites de la Reine de Saba by Michalon (2002) mentions the preface written by C.G. Jung, but only goes so far as to describe Serrano as an "écrivain et diplomate chilien né en 1917, [qui] appartient à une galaxie d'écrivains dont fait également partie son ami Hermann Hesse ou encore Ezra Pound". Consequently, we can say that Serrano's strategy of self-authorization, through the exaggerated and mystified relationship with two key intellectual figures of his time, continues to prove effective in the realm of esoteric World Literature. Furthermore, these attempts seem to have not yet 


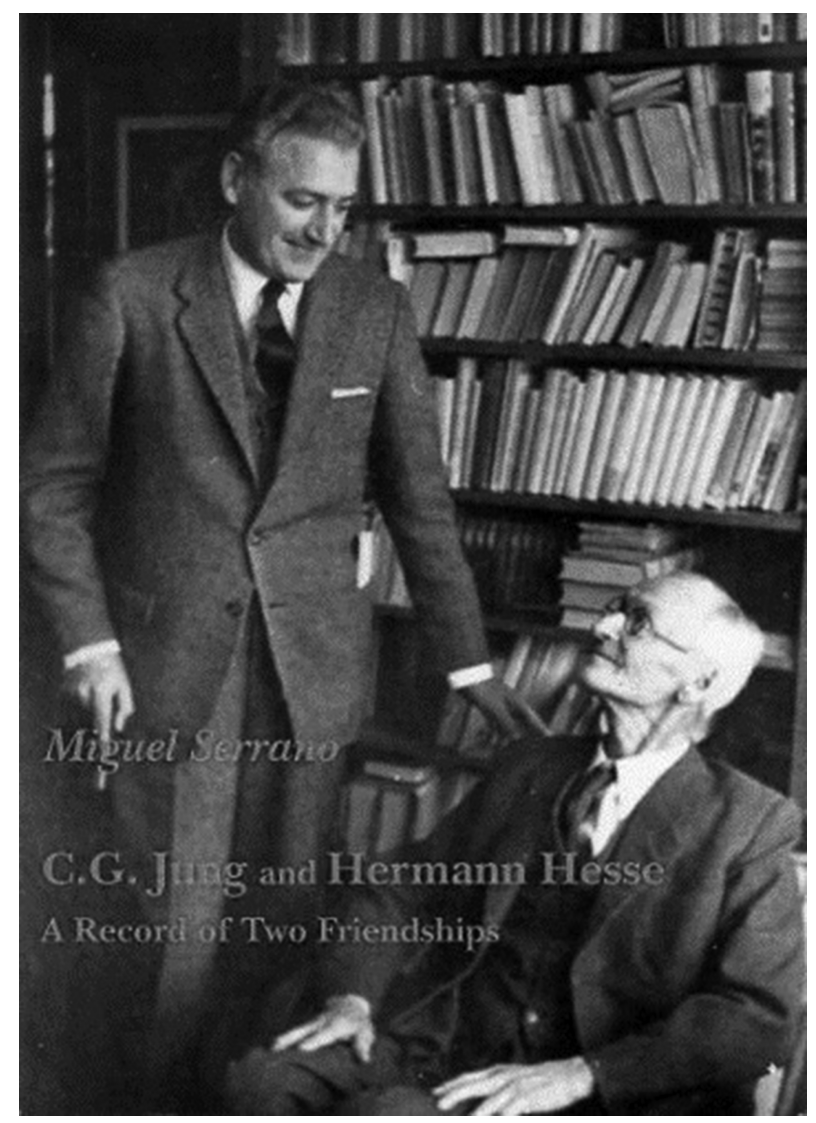

Figure 2: Cover of the English translation of El círculo hermético. ( Daimon Verlag AG 2012.

been overshadowed by the second dimension of his doubtful legacy: his contributions to an overtly Fascist World Literature.

\section{IV “Esoteric Hitlerism”: Miguel Serrano's Fascist World Literature}

If, in some cases, it may be difficult to categorize ideological positions as conservative, reactionary, or fascist, this problem does not apply to Miguel Serrano, who has never denied his Nazi convictions. The denial of the Holocaust, the mockery 
of Augusto Pinochet's dictatorship's victims in Chile ${ }^{5}$, the dedication of several of his books to Adolf Hitler, as well as speeches to honor Rudolf Hess and Walter Rauff, the inventor of the mobile gas chamber that was flown to Chile, are only some of the most abject entrees in Serrano's extensive Nazi-supporting record. Additionally, throughout his lifetime Serrano maintained a worldwide network of contacts and friendships with notorious historical Nazi figures, such as Léon Degrelle $^{6}$, Julius Evola, and Herman Wirth, as well as with neo-Nazi leaders, such as Matthias Koehl in the United States (cf. Goodrick-Clark 2002: 190-191). All of these contacts more than likely contributed to the fact that Serrano's fascist works have been circulating around the world for the past 50 years and still continue to do so today. In Chile, Serrano's widow, the Spanish historian María Isabel Pérez Quintela, founded the publishing house ED Libros in order to disseminate Serrano's archive, work, and legacy. On an international scale, mainly small independent neo-Nazi and right-wing publishers have translated and spread Serrano's works. Another important channel have been, as Goodrick-Clark states, neo-Nazi magazines (Goodrick-Clark 2002: 191). Considering the fact that, particularly with regard to Latin American literature, the scholarship on World Literature has unreservedly advocated the work of independent publishers as a counter-balance to multinational consortia, the global circulation of Serrano's Nazi literature proves that a world of reactionary independent publishing, without which a global circulation of these ideologies would be hard to imagine, also exists.

In Germany, Serrano's trilogy on "esoteric Hitlerism” was published first in 1987 by the Nazi publisher Teut-Verlag, run by Richard Schepmann, the son of a former SA officer (Goodrick-Clark 2002: 163). Although officially banned by German authorities in the early 90s, Serrano's fascist literature has been recently re-edited in Germany by the publisher Der Schelm, based in Leipzig and run by Adrian Preißinger, a neo-Nazi music producer who was convicted of incitement to hatred. In addition to a new edition of Das Goldene Band Esoterischer Hitlerismus, Der Schelm published a new "deluxe edition" of Adolf Hitler - Der letzte Avatar in February 2020 (Figure 3).

In France, Serrano's books have been published by equally dubious publishers, such as Curutchet and Ars Magna. The founder of the first, Jean Curutchet, was convicted to a life sentence due to crimes committed during the

5 Although Serrano naturally welcomed the coup in 1973 and had been in direct contact with Pinochet in the 1970s and 1980s, he finished by criticizing the military government both for its inability to bring to an end a truly racial cleansing of Chile and for its implementation of a fierce neoliberalism (cf. Serrano 1987).

6 For more on Léon Degrelle, see, for example, Jonathan Littell's essay Le sec et l'humide. 


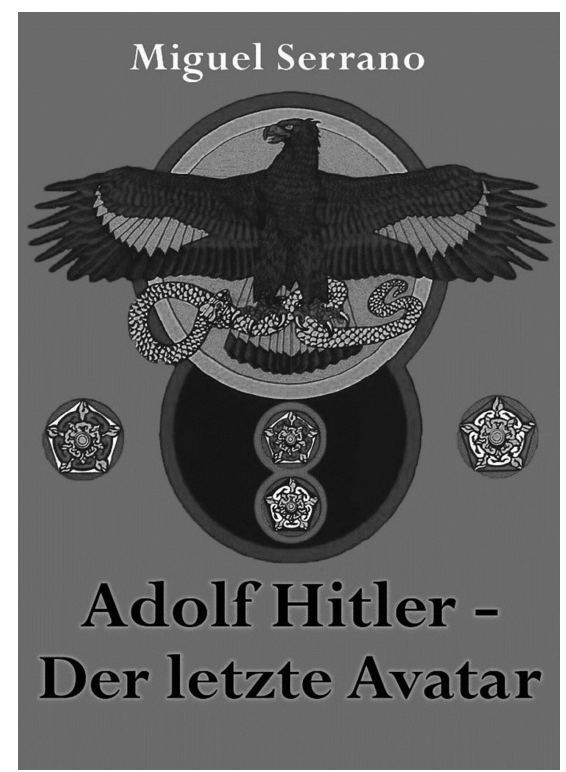

Figure 3: Cover of the German translation of Adolf Hitler - el último avatar. (c) Editorial Solar 2011.

Algerian War before being pardoned by the French state and founding his publishing house in French Basque Country. Ars Magna, a publisher founded in 1996 in Nantes, has published several books by Serrano in the past years and specifies its mission on its home page as “centré sur l'histoire des mouvements d'orientation nationaliste-révolutionnaire et traditionaliste, sur la géopolitique et sur la traduction de textes idéologiques rares inédits dans notre langue”. It is owned by Christian Bouchet, a well-known French right-wing politician and member of the Front (today: Rassemblement) National, who also published a book by Sevitri Devy in Avatar, a French-Italian transnational right-wing publishing project. In Italy, several of Serrano's works have recently been published by Settimo Sigillo, a Roman neo-fascist publisher founded by Enzo Cipriano, who is also an active member of the Italian neo-fascist movement CasaPound. The best proof of the vitality of Serrano's work in Italy, however, might be the publication of Il dizionario di Miguel Serrano in 2019 by the Tuscan historian Renzo Giorgetti. The book was published by the newly created far right publisher, Passaggio al bosco, named after Ernst Jünger's classic Der Waldgang. In the English-speaking world, Serrano's Fascist World Literature has been widely translated and read, disseminated by underground neo-Nazi publishing projects, such as The Patriot Press in Nevada and the Hermitage Helm Corpus in Australia. 
This short panorama should be proof enough that Miguel Serrano's work possesses a consolidated presence within a global canon of neo-Fascist World Literature, which, in view of the current ideological rollback around the globe, has been finding new publishers and readers alike. The fact that - as it is in France or Italy - publishers and cultural agents of the Far Right are, at the same time deeply involved in neo-fascist political projects, aspiring to overthrow the democratic systems whose freedom of speech makes the circulation of their anti-democratic ideologies possible at all, opens up the question of how to deal with authors like Miguel Serrano, not only from an aesthetic, but from a political and legal point of view as well.

\section{Fascist Aesthetics and Politics: Impossible Separations}

"Sé que mi adhesión al nazismo me ha cerrado puertas. Yo lo sabía, pero si cortara eso, me estaría mutilando a mí mismo, porque no hay ninguna dicotomía entre mi obra, la que dicen puramente literaria, y mi manera de pensar" (Serrano in Cárdenas 2009: s.p.). The irony of these words said by Miguel Serrano lies in the fact that they undermine the common argument of those who defend reactionary authors, namely that freedom of art and the notion of art as an autonomous aesthetic realm has both permitted and protected positions of political and ideological extremism. Serrano obviously did not want any difference to be made between his political positions and his literary work; he meant every word. Bearing this in mind, the treatment of Serrano's reputation and his legacy, particularly in Chile, is not only bizarre, but disturbing. The examples are numerous. In 2002 Serrano was invited onto a well-known TV program, La belleza de pensar, where famous authors, such as José Saramago or Roberto Bolaño, have made an appearance. The host, journalist and writer Cristián Warnken, talked to Serrano for an hour without even mentioning his contemptuous ideological and aesthetic positions. Instead, the conversation was basically about Serrano's preference for tantrism and other relics of esotericism, giving off the impression that he was a somewhat funny, but inoffensive old man. Similarly, Serrano's work and personal life are represented in all dimensions on memoriachilena, the country's biggest digital repository of the history of arts and literature, run by the Biblioteca Nacional de Chile. The source of all of this irritation is that he appears in what is essentially a digital pantheon of Chilean literature in a totally normalized way. His overtly racist and anti-Semitic work is covered up solely by a commentary that, "De regreso en 
Chile, en la década de 1980, se dedicó a los temas del nacionalsocialismo y publicó la Trilogía del hitlerismo esotérico", as if Serrano had been some sort of researcher specializing in the study of Nazism rather than one of its most important historical propagandists in Latin America.

The question here is obviously whether or not a state-run cultural institution can and should maintain a neutral position towards writings like those of Miguel Serrano; writings that are not simply morally abject, but also incite its readers to overthrow democracy and praise some of the worst mass murderers of the history of humankind. The problem with this neutrality is that it promotes the impression that fascism might be a sort of political "opinion" like all the others, which is clearly not the case. Chilean writer and critic Rafael Gumucio probably expressed it best when he wrote that Serrano's “esoteric Hitlerism" "podría ser folclórico y divertido si esta tolerancia con el horror, si ésta fascinación por las botas prusianas de los miliares, si este amor por las nieves eternas, si este desprecio por la historia y el dolor ajeno no hubiesen creado nuestros propios campos de concentración" (Gumucio 2010: 103). Apart from the fact that Serrano's works (the only potential exception being his very early writings from the 1950s about his travels to Antarctica) are aesthetically poor, even downright kitschy (as much as his proponents would like him to be a sort of Chilean Céline), the political implication of his aesthetic choices arise from the fact that his works' mythological notion of history, language, and race are deliberately structurally identical to the ideological and aesthetic fundaments of Nazism itself. Or, as Gumucio put it, "Ser nazi, serlo como lo es Serrano, con perseverancia y alevosía, es dar por cierta toda una serie de fantasías medievales e hindúes, invisibles e improbables, y pensar que los muy visibles y probados hornos de Auschwitz son una ilusión o un mal menor" (Gumucio 2010: 105).

What can we make out of these reflections? The consequence should not be to ban or to censor fascist authors like Miguel Serrano, but to read Reactionary (World) Literature, particularly in view of the global return of Fascist politics and aesthetics (cf. Loy 2019). Obviously, these readings - and this could be an important ethical task for the somewhat under-politicized scholarship on World Literature - should contribute to an informed way of deconstructing Fascist World Literature, its aesthetics, and its enabling structures and actors. The effect this would have would be to recognize that an author like Miguel Serrano can and should not be read in merely "aesthetical" terms, which is, as he stated himself, simply impossible. It would mean properly contextualizing the abject dimension of his thinking and literature instead of placing him indiscriminately within the history of literature, or just considering him a bizarre and fascinating 
phenomenon ${ }^{7}$. It would certainly also mean sincerely asking every one of his readers or aesthetic defenders whether or not she or he actually understands what kind of death-bringing tradition they are affiliating themselves with when insisting on an impossible separation between fascist aesthetics and politics.

\section{Works Cited}

Ars Magna (eds.) (2003): Miguel Serrano, un Esotérisme Hitlérien. Nantes: Éditions Ars Magna.

Bogdan, Henrik/Djurdjevic, Gordan (2013): "Introduction. Occultism in a global perspective". In: Bogdan, Henrik/Djurdjevic, Gordan (eds.): Occultism in a Global Perspective. Durham: Acumen, pp. 1-16.

Camus, Jean-Yves (2013): “The European Extreme Right and Religious Extremism”. In: Mammone, Andrea/Godin, Emmanuel/Jenkins, Brian (eds.): Varieties of Right-Wing Extremism in Europe. London/New York: Routledge, pp. 107-120.

Cárdenas, María Teresa (2009): “Serrano y Teitelboim: un diálogo interrumpido”. In: Revista de Libros de El Mercurio, 8/03/2009, < http://letras.mysite.com/ms0903092.html> (last visit: 22/02/2020).

Dohe, Carrie B. (2016): Jung's Wandering Archetype. Race and Religion in Analytical Psychology. London/New York: Routledge.

Durham, Martin/Power, Margret (eds.) (2010): New Perspectives on the Transnational Right. New York: Palgrave Macmillan.

Eco, Umberto (1995): The Search for the Perfect Language. Transl, James Fentress. Oxford: Blackwell.

Figueroa, Natalia (2018): Ideologías excluyentes en la literatura chilena: Braulio Arenas, Eduardo Anguita y Miguel Serrano. Santiago de Chile: historia chilena.

Finchelstein, Federico (2010): Transatlantic Fascism: Ideology, Violence, and the Sacred in Argentina and Italy, 1919-1945. Durham: Duke University Press.

Giorgetti, Renzo (2019): Il dizionario di Miguel Serrano. Florence: Passaggio al bosco. Goodrick-Clarke, Nicholas (2002): Black Sun: Aryan Cults, Esoteric Nazism and the Politics of Identity. New York: New York University Press.

Gumucio, Rafael (2010): “El eterno retorno de Miguel Serrano”. In: Rafael Gumucio: La situación. Crónica literarias. Santiago de Chile: Ediciones Universidad Diego Portales, pp. 103-106.

Kurlander, Eric (2018): Hitler's Monsters: a Supernatural History of the Third Reich. New Haven: Yale University Press.

León, Gonzalo (2017): Serrano. Buenos Aires: Mansalva.

Littell, Jonathan (2008): Le sec et l'humide. Paris: Gallimard.

7 The recent semi-fictional essay Serrano by Chilean writer Gonzalo León promotes this form of a fascinated reading of Serrano's figure and work. I owe thanks to my colleague Karen Genschow for drawing my attention to this book. 
Loy, Benjamin (2020): “The Reactionary Genealogies of Latin American Literature”. In: De Ferrari, Guillermina/Siskind, Mariano (eds.): The Routledge Companion to Twentieth and Twenty-First Century Latin American Literary and Cultural Forms. New York/ London: Routledge. (in press).

Loy, Benjamin (2019): “'The Global Alt-Write’ or Why We Should Read Reactionary (World) Literature”. In: Müller, Gesine /Siskind, Mariano (eds.): World Literature, Cosmopolitanism, Globality: Beyond, Against, Post, Otherwise. Berlin/Boston: De Gruyter, pp. 111-127.

Mammone, Andrea/Godin, Emmanuel/Jenkins, Brian (eds.) (2013): Varieties of Right-Wing Extremism in Europe. London: Routledge.

Mani, B. Venkat (2017): Recording World Literature. Libraries, Print Culture, and Germany's Pact with Books. New York: Fordham University Press.

Martin, Benjamin G. (2016): The Nazi-fascist New Order for European Culture. Cambridge: Harvard University Press.

Marling, William (2016): Gatekeepers: the Emergence of World Literature and the 1960s. New York: Oxford University Press.

Mosse, George (1966): The Crisis of German Ideology. Intellectual Origins of the Third Reich. London: Weidenfield and Nicolson.

Müller, Gesine/Siskind, Mariano (eds.) (2019): World Literature, Cosmopolitanism, Globality: Beyond, Against, Post, Otherwise. Berlin/Boston: De Gruyter.

Rosa, Hartmut (2019): Resonance: a Sociology of the Relationship to the World. Transl. James Wagner. Cambridge: Polity Press.

Sapiro, Gisèle (2016): “How Do Literary Works Cross Borders (or Not)? A Sociological Approach to World Literature". In: Journal of World Literature 1/1, pp. 81-96.

Sedgwick, Mark (2004): Against the Modern World. Traditionalism and the Secret Intellectual History of the Twentieth Century. New York: Oxford University Press.

Serrano, Miguel (2020): Adolf Hitler. Der letzte Avatar. Transl. N.N. Leipzig: Der Schelm.

Serrano, Miguel (2019): Das Goldene Band - Esoterischer Hitlerismus. Transl. F. Urtho. Leipzig: Der Schelm.

Serrano, Miguel (2010): Adolf Hitler, l'ultimo Avatara. Rome: Settimo Sigillo-Europa Lib. Ed.

Serrano, Miguel (2005): Hipocresía. La tortura en Chile. Santiago de Chile: Ediciones La Nueva Edad.

Serrano, Miguel (2002): Les visites de la Reine de Saba. Transl. Bruno Dietsch. Paris: Michalon.

Serrano, Miguel (1999): Nietzsche et l'éternel retour. Transl. Bruno Dietsch. Hélette: Jean Curutchet.

Serrano, Miguel (1996): Epistolario para impedir el fin de Chile. Santiago de Chile: Autor.

Serrano, Miguel (1987): Nacionalsocialismo, única solución para los Pueblos de América del Sur. Bogotá: Editorial Solar.

Serrano, Miguel (1986): La resurrección del héroe. Santiago de Chile: Alfabeta Impresores.

Serrano, Miguel (1986): Le cercle hermétique: testaments littéraires de Hermann Hesse et Carl-Gustav Jung. Transl. B. Goorden. Brussels: Recto-verso.

Serrano, Miguel (1984): Auf der Suche nach der verborgenen Blume: eine südamerikanische Legende. Transl. Susanne Seiler. Basel: Sphinx-Verlag.

Serrano, Miguel (1982): El-ella: das Buch der magischen Liebe. Transl. Jan Erik Sigdell. Basel: Sphinx-Verlag. 
Serrano, Miguel (1974): El círculo hermético. El eterno retorno. Elella. Santiago de Chile:

Ediciones Nueva Universidad.

Serrano, Miguel (1973): The Vistis of the Queen of Sheba. Transl. Frank MacShane. New York: Harper \& Row.

Serrano, Miguel (1972): The Serpent of Paradise: The Story of an Indian Pilgrimage. Transl. Frank MacShane. New York: Harper \& Row.

Serrano, Miguel (1969): The Ultimate Flower. Transl. Frank MacShane. London: Routledge \& Kegan.

Serrano, Miguel (1968): Meine Begegnungen mit C.G. Jung und Hermann Hesse in visionärer Schau. Transl. Alice Maurer. Zürich/Stuttgart: Rascher.

Versluis, Arthur (2013): "Savitri Devi, Miguel Serrano, and the Global Phenomenon of Esoteric Hitlerism”. In: Bogdan, Henrik/Djurdjevic, Gordan (eds.): Occultism in a Global Perspective. Durham: Acumen, pp. 121-134. 